\title{
PENINGKATAN CITRA DAN KEPERCAYAAN MASYARAKAT PADA RUMAH SAKIT MILIK PEMERINTAH MELALUI PERBAIKAN SISTEM PENYAMPAIAN JASA
}

\author{
Rahab (rahab_inc@yahoo.co.id) \\ Alisa Tri Nawarini (alisa_tri_nawarini@yahoo.co.id) \\ Fakultas Ekonomi Universitas Jenderal Soedirman
}

\begin{abstract}
The aims of this research is to analyze: 1) the effect of physical support to contact personnel, 2) the effect of service delivery systems that consist of physical support and contact personnel to hospital image, 3) the effect of service delivery systems that consist of physical support and contact personnel to hospital consumer trust', 4) the effect of hospital image to consumer trust'. This research is a quantitative research. This research is descriptive and verivicative research with descriptive and explanatory survey methods. Type of investigation in this research is causality with time coverage is cross sectional. Sampling method used in this research is multistage sampling by taking four public hospital in Banyumas residence with 100 hospital consumers' as respondents (patients and their family). Data analysis methods used in this research are descriptive analysis and path analysis. The research results show that: 1) Physical support correlate to contact personnel, 2) physical support affecting hospital image, 3) contact personnel is not affecting hospital image, 4) physical support affecting consumers' trust, 5) contact personnel affecting consumers' trust, 6) hospital image affecting consumers' trust.
\end{abstract}

Keywords: service delivery systems, physical support, contact personnel, hospital image, consumers' trust

\section{PENDAHULUAN}

Industri jasa kesehatan mempunyai prospek yang cukup bagus, karena pelayanan kesehatan tidak terpaku hanya pada pengobatan penyakit tetapi juga memberikan pelayanan untuk usaha pencegahan dan meningkatkan kesehatan. Hal ini dapat sarana bagi pemberi jasa pelayanan kesehatan untuk memberikan pelayanan yang sesuai dengan harapan masyarakat sebagai pemakai jasa kesehatan. Berdasarkan temuan Hardiman (2003), sistem pelayanan kesehatan di Indonesia belum baik. Rumah sakit belum mampu menjamin mutu pelayanan kesehatan, misalnya dokter sering terlambat datang, pasien harus menunggu lama untuk mendapat pelayanan, belum menyediakan ruang tunggu yang nyaman, belum ada kontinuitas pelayanan, belum bisa menjamin waktu penyerahan obat serta belum mampu membuat sistem peresepan on line lewat komputer. Masih banyak rumah sakit yang belum consumer oriented, belum memberikan kemudahan akses pelayanan bagi pasien.

Permasalahan yang dihadapi rumah sakit dalam rangka memberikan kepuasan pada pengguna umumnya berkaitan dengan sistem penyampaian jasa yang meliputi physical support dan contact personnel. Physical support adalah berbagai fasilitas fisik dan komponen pelengkap dari suatu jasa yang ditawarkan rumah sakit, sedangkan contact personnel adalah tenaga medis, paramedis dan non medis yang ikut terlibat dalam penyampaian jasa dan mempunyai kontak langsung dengan pasien dan keluarganya. Berdasarkan pengamatan sementara pada rumah sakit rumah sakit umum daerah (RSUD) Banyumas diperoleh informasi bahwa physical support yang dimiliki oleh pihak rumah sakit belum baik, seperti segi penataan ruang layanan yang masih kurang teratur, ketidaknyamanan ruang tunggu dan perawatan, tempat parkir yang terbatas, eksterior 
dan interior yang kurang menarik, kesulitan mendapatkan obat, sarana pendukung (seperti wartel, ATM, toko dan bank) yang terbatas. Demikian juga dengan contact personnel dimana masih terlihat petugas yang tidak menyenangkan, kurang ramah, penampilan yang belum rapi dan menarik, prosedur penerimaan yang sulit, informasi yang kurang jelas dan keterlambatan dalam pelayanan karena menunggu Dokter. Hal ini akan membuat masyarakat tidak tertarik berobat ke rumah sakit umum dan memilih alternatif pelayanan kesehatan yang lain seperti rumah sakit khusus, rumah sakit umum di daerah lain, poliklinik, Puskesmas, pengobatan tradisional dan alternatif, yang dipercayai mampu menyembuhkan dan memiliki kualitas lebih baik. Berdasrkan hasil penelittain Rahab (2011) menemukan bahwa physical support dan contact personnel mempunyai pengaruh pada citra rumah sakit bagi penggunannya. Namun bagaimana physical support dan contact personnel dapat meningkatkan kepercayaan pengguna terhadap rumah sakit pemerintah belum dikaji secara komprehensif. Selain itu Rahab (2011) belum mengkaji hubungan antara citra dengan kepercayaan pengguna. Padahal dari beberapa penelitian menyebutkan bahwa ada pengaruh dimensi citra perusahaan pada kepercayaan penggunanya ((Shamdasani dan Balakrishnan, 2000; Kotler, 2003).

Berdasarkan pemikiran-pemikiran tersebut dan untuk mendapatkan bukti empirik, maka diperlukan penelitian berkenaaan dengan pengaruh sistem penyampaian jasa terhadapcitra rumah sakit dan dampaknya terhadap kepercayaan pelanggan pada rumah sakit umum di wilayah Kabupaten Banyumas. Dalam artikel ini akan dibahas empat permasalahan : pertama, bagaimanakah sistem penyampaian jasa meliputi physical support dan contact personnel, citra rumah sakit serta kepercayaan pelanggan pada rumah sakit umum di Wilayah Kabupaten Banyumas. Kedua, sejauhmana hubungan antara physical support dengan contact personnel pada rumah sakit umum di Wilayah Kabupaten Banyumas. Ketiga, sejauhmana sistem penyampaian jasa yang meliputi physical support dan contact personnel berpengaruh terhadap citra rumah sakit umum di Wilayah Kabupaten Banyumas dan keempat, sejauhmana sistem penyampaian jasa yang meliputi physical support dan contact personnel serta citra rumah sakit berpengaruh terhadap kepercayaan pelanggan pada rumah sakit umum di Wilayah Kabupaten Banyumas.

\section{TINJAUAN PUSTAKA}

Sistem Penyampaian Jasa

Menurut Lovelock dan Wright (2002), bisnis jasa dipandang sebagai suatu sistem terdiri dari sistem operasi jasa (service operation system) dan system penyampaian jasa (service delivery system). Pada sistem operasi jasa (service operation system), merupakan komponen yang terdapat dalam sistem bisnis jasa keseluruhan, dimana input diproses dan elemen-elemen produk jasa diciptakan melalui komponen sumber daya manusia dan komponen fisik. . Sebagai suatu sistem, bisnis jasa terdiri dari sistem operasi jasa, dan sistem penyampaian jasa yang merupakan bagian-bagian yang dapat dilihat oleh konsumen (front office) yaitu physical support dan contact personnel yang saling berhubungan satu sama lainnya, dan bagian yang tidak terlihat oleh konsumen (back office), dimana konsumen menganggapnya sebagai kegiatan teknis inti, bahkan yang keberadaannya tidak diketahui oleh konsumen, tapi bisa dirasakan oleh konsumen hasil kegiatannya. Kotler mengistilahkan dengan inanimate environment dan contact personnel atau service provider (Kotler; 2003).

\section{Physical Support}

Menurut Nguyen dan Leblanc $(2002,1996)$ lingkungan fisik diukur dengan ambient conditions, atmosfir, rancangan eksterior, rancangan interior, dekorasi, fasilitas parkir, penampilan gedung dan taman serta lokasi. Ambient conditions terdiri dari bermacammacam elemen seperti warna, penerangan, temperatur, kebisingan, bau dan musik. 
Shamdasani dan Balakrishnan (2000) lingkungan fisik diukur dengan ambient, simbol dan benda. Pada rumah sakit lingkungan fisik mencakup lokasi, peralatan dan fasilitas, yang dianggap penting oleh pasien rumah sakit (Hutton dan Richardson, 1995).

Lokasi merupakan kestrategisan letak rumah sakit baik dihubungkan dengan fasilitas umum maupun kemudahan untuk mencapainya. Hal ini sesuai dengan pendapat Hesket et.al (1997) bahwa salah satu elemen dalam sistem penyampaian jasa adalah lokasi, sedangkan Boy S. (2004) menyatakan lokasi digunakan untuk mencapai pelanggan yang dituju dan memerlukan waktu yang relatif cepat. Fasilitas fisik merupakan benda-benda tidak bergerak, nyata dan dapat dirasakan oleh pasien seperti peralatan yang representatif, interior bangunan yang asri, eksterior bangunan, fasilitas parkir, kantin, bank, dan jaminan keamanan. Peralatan rumah sakit merupakan peralatan yang dimiliki rumah sakit yang berkaitan langsung dengan kebutuhan pasien, sedangkan menurut Hutton dan Richardson (1995) makanan yang disediakan dapat dibuat juga sebagai bagian bukti fisik pada rumah sakit.

Fasilitas yang dilihat konsumen merupakan bagian dari wujud nyata yang penting atas keseluruhan jasa yang ditawarkan (Lamb et al, 2002). Tingkat kenyamanan dalam rumah sakit juga perlu diperhatikan disamping fasilitas dan peralatan. Hal ini sesuai dengan pendapat Boy S. (2004) juga menyatakan rumah sakit perlu menjaga kenyamanan disamping peralatan yang memadai, sedangkan hasil penelitian Joseph and Cindy (1999) dalam industri jasa perbankan bahwa tingkat kenyamanan berpengaruh terhadap kualitas sistem penyampaian jasa.

Selain itu tata letak ruangan dan prosedur pelayanan yang diberikan petugas merupakan unsur yang penting dalam penyampaian jasa. Menurut Heskett (1996) juga menyatakan bahwa sistem penyampaian jasa sebagai hal yang penting dan berhubungan tata ruang, tata letak dan prosedur kerja.

\section{Contact Personnel}

Contact personnel merupakan semua unsur manusia yang ikut terlibat dalam penyampaian jasa dan mempunyai kontak langsung dengan pembeli. Menurut Nguyen dan Leblanc (2002) contact personnel tersusun dari seluruh karyawan yang berada pada lini depan organisasi dan mempunyai kontak langsung dengan pelanggan. Menurut Snook (1992) staff medis rumah sakit adalah dokter, dokter gigi, ahli penyakit kaki, dan staf profesional kesehatan yang merawat pasien. Lim et al (2000) menemukan unsur yang terpenting dalam pelayanan pada rumah sakit adalah Dokter dan perawat. Dokter dan perawat berperanan penting dalam menciptakan kualitas pelayanan pada suatu rumah sakit, sedangkan Fox et al (2003) yang menemukan bahwa dokter dan perawat berperanan mendorong kesembuhan pasien, terutama keramahan dan perhatian khusus mereka kepada pasien.

\section{Citra Perusahaan}

Citra merupakan persepsi masyarakat terhadap perusahaan atau produknya (Kotler, 2003). Citra perusahaan digambarkan sebagai kesan keseluruhan yang dibuat dalam pikiran masyarakat tentang suatu organisasi. (Barich dan Kotler 1991, dalam Nguyen dan Leblanc, 2002). Citra perusahaan yang akan dibahas dalam penelitian ini adalah citra yang dilihat dari sudut pandang konsumen (pengguna), seperti yang didefenisikan oleh Kotler. Penelitian ini berbeda dengan penelitian yang dilakukan oleh Riordan et.al (1997), dimana ia memandang dari perspektif employee reaction. Menurut Leblanc dan Nguyen (1996) faktor-faktor yang dapat mempengaruhi citra perusahaan jasa adalah identitas perusahaan, reputasi, tanda- tanda yang tangible, contact personnel dan tingkatan jasa. 


\section{Kepercayaan Pelanggan}

Secara konseptual, kepercayaan (trust) ada jika suatu pihak punya keyakinan (confidence) terhadap integritas dan reliabilitas pihak lain (Morgan dan Hunt, 1994), sedangkan Deshpande dan Zaltman (1993 dalam Morgan dan Hunt, 1994) menyatakan kepercayaan sebagai kemauan untuk mempercayai pihak lain yang telah diyakini. Kedua defenisi digambarkan oleh Rotters (1967) bahwa kepercayaan adalah harapan secara umum seseorang atau dengan kata lain dapat dipercaya. Kedua defenisi juga menekankan pentingnya kepercayaan. Rousseau (1998) menyatakan kepercayaan (trust) adalah keadaan psikologis berisi keinginan untuk menerima kekurangan/kelemahan, berdasarkan perilaku yang positif terhadap intensi atau perilaku atau lainnya dalam keadaan berisiko dan saling tergantung, sedangkan Robbin (2003) menyatakan kepercayaan (trust) merupakan harapan yang positif bahwa yang lain tidak akan bertindak secara oportunistic. Menurut Callaghan, et.al, 1995 dan Bologlu (2002) dimensi kepercayaan didefenisikan sebagai dimensi hubungan bisnis yang menentukan tingkat dimana orang merasa dapat bergantung pada integritas janji yang ditawarkan oleh orang lain. Mengacu pada ketentuan di bidang psikologi sosial dan pemasaran, Donney and Cannon (1997) mendefinisikan "Trust as perceived credibility and benevolence of a target of trust." Dari definisi ini trust dapat dilihat dari dua dimensi. Dimensi pertama adalah credibility of an exchange partner, and ecpectancy that the partner word or written statement can be relied on. Dimensi kedua benevolence is the extent to wish one partner is genuinely interested in the other partner's welfare and motivated to seek joint again.

\section{Kerangka Teori}

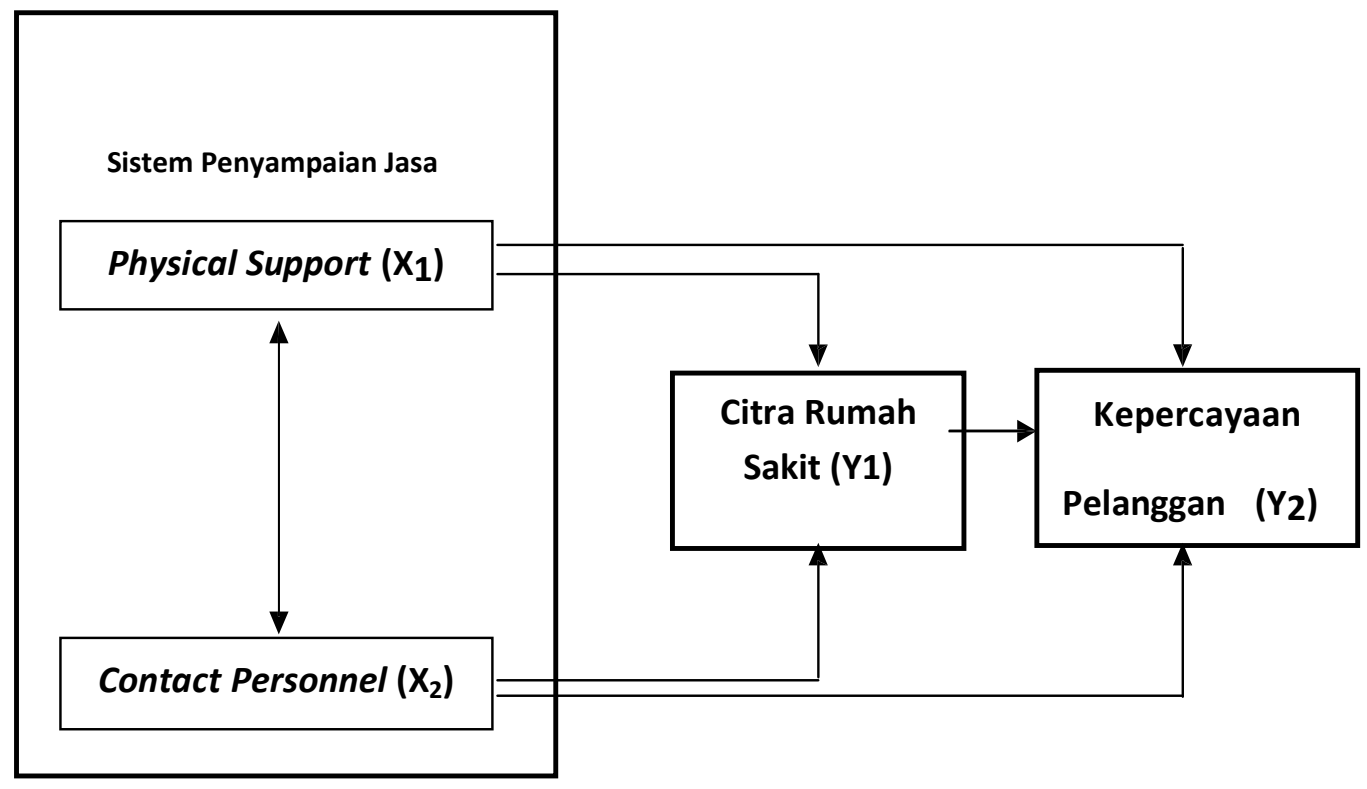

\section{HIPOTESIS}

$\mathrm{H}_{1}$ : Terdapat hubungan antara physical support dengan contact personnel pada rumah sakit umum milik pemerintah di Wilayah Kabupaten Banyumas

$\mathrm{H}_{2}$ : Physical Support berpengaruh positif terhadap citra rumah sakit

$\mathrm{H}_{3}$ : Contact Personnel berpengaruh positif terhadap citra rumah sakit

$\mathrm{H}_{4}$ : Physical Support berpengaruh positif terhadap kepercayaan pelanggan

$\mathrm{H}_{5}$ : Contact Personnel berpengaruh positif terhadap kepercayaan pelanggan

$\mathrm{H}_{6}$ : Citra rumah sakit berpengaruh positif terhadap kepercayaa pelanggan 


\section{METODE PENELITIAN}

Jenis penelitian adalah penelitian deskriptif verifikatif karena penelitian ini bertujuan untuk mendapatkan gambaran dan informasi tentang sistem penyampaian jasa yang meliputi physical support dan contact personnel dan menguji mengenai pengaruhnya terhadap citra rumah sakit dan kepercayaan pelanggan pada rumah sakit umum milik pemerintah yang berada di wilayah Kabupaten Banyumas. Metode penelitian yang digunakan adalah metode survey.

Populasi sasaran dalam penelitian ini adalah seluruh pasien yang pernah mendapatkan pelayanan pada rumah sakit umum milik pemerintah yang berada di wilayah Kabupaten Banyumas yang berjumlah 4 rumah sakit. Rumah sakit tersebut meliputi: RSUD Banyumas, RSUD Aibarang, RSUP Margono Sukarjo dan RS Geriatri Margono Soekarjo. Dalam penelitian ini, teknik penarikan sampel yang digunakan adalah purposive sampling. Sampel yang diambil sampel penelitian sebanyak 100 pelanggan yang didistribusikan secara acak dan dialokasikan secara proporsional pada setiap rumah sakit umum.

Definisi Operasional Variabel

1. Physical support

Physical support adalah hal yang berkaitan dengan fasilitas fisik dan komponen pelengkap dari suatu jasa yang ditawarkan. Indikatornya adalah fasilitas gedung yang tersedia, ketersediaan peralatan,ketersediaan sarana parkir,kenyamanan rumah sakit,keamanan rumah sakit,ketersediaan fasilitas pendukung,kondisi ruang perawatan,kebersihan rumah sakit,eksterior gedung,interior gedung,kelengkapan obat di apotik,kestrategisan lokasi rumah sakit,penerangan rumah sakit,sirkulasi udara,tata letak ruangan, menu makanan yang disediakan.

2. Contact personnel

Contact personnel adalah semua unsur manusia yang ikut terlibat dalam penyampaian jasa dan mempunyai kontak langsung dengan pembeli. Indikatornya adalah penampilan tenaga medis dan non medis saat memberikan pelayanan, kemampuan tenaga medis dan non medis saat memberikan pelayanan,keramahan tenaga medis dan non medis saat memberikan pelayanan, daya tanggap tenaga medis dan non medis saat memberikan pelayanan,kecepatan tenaga medis dan non medis saat memberikan pelayanan, kemudahan untuk menemui tenaga medis dan non medis,ketepatan waktu pelayanan,kemudahan prosedur pelayanan petugas,kejelasan informasi yang diberikan petugas.

3. Citra rumah sakit

Citra rumah sakit adalah kesan atau perasaan masyarakat terhadap rumah sakit. Indikatornya adalah pendapat responden mengenai rumah sakit,pendapat responden terkait dengan kontribusi rumah sakit terhadap masyarakat,kesukaan terhadap rumah sakit.

4. Kepercayaan pelanggan

Kepercayaan pelanggan adalah keyakinan pelanggan terhadap integritas dan kehandalan rumah sakit. Indikatornya adalah kepercayaan akan kehandalan rumah sakit,kepercayaan konsumen untuk sembuh jika berobat ke rumah sakit,kepercayaan terhadap kualitas peralatan yang dimiliki rumah sakit,kepercayaan terhadap pelayanan rumah sakit yang diberikan/melakukan sesuai janji yang diberikan.

Data hasil penelitian akan dianalisis dengan menggunakan analisis jalur (Path Analysis) yang terdiri dari dua substruktur. Substruktur pertama akan menganalisis besarnya pengaruh physical support dan contact personnel terhadap citra rumah sakit, sedangkan substruktur kedua akan menganalisis besarnya pengaruh physical support, contact personnel dan citra rumah sakit terhadap kepercayaan pelanggan rumah sakit. 


\section{HASIL PENELITIAN DAN ANALISIS}

Hipotesis pertama diuji dengan cara melihat nilai korelasi antara variabel physical Support dan contact personnel. Dari hasil uji statistik dikeetahui bahwa besarnya nilai korelasi antara variabel physical Support dan contact personnel adalah sebesar 0,661. Angka korelasi tersebut mempunyai maksud bahwa hubungan antara physical support dan contact personnel kuat dan searah (karena hasilnya positif). Korelasi antara physical support dan contact personnel bersifat signifikan karena angka siginifikasi penelitian sebesar $0,00<0,05$, sehingga dengan demikian dapat dinyatakan bahwa hipotesis pertama penelitian ini diterima $\left(\mathbf{H}_{1}\right.$ diterima).

Untuk pengujian hipotesis kedua hingga kelima, dilakukan dengan memandingkan nilai † hitung dengan $t$ tabel. Hasil dari uji hipotesis tersebut adalah sebagai berikut:

\begin{tabular}{|l|c|c|c|}
\hline \multicolumn{1}{|c|}{ Hipotesis } & T hitung & T tabel & Simpulan \\
\hline $\begin{array}{l}\mathrm{H}_{2}: \text { Physical Support berpengaruh } \\
\text { positif terhadap citra rumah sakit }\end{array}$ & 2,825 & 1,661 & $\mathrm{H}_{2}$ diterima \\
\hline $\begin{array}{l}\mathrm{H}_{3}: \text { Contact Personnel berpengaruh } \\
\text { positif terhadap citra rumah sakit }\end{array}$ & 0,915 & 1,661 & $\mathrm{H}_{3}$ ditolak \\
\hline $\begin{array}{l}\mathrm{H}_{4}: \text { Physical Support berpengaruh } \\
\text { positif terhadap kepercayaan } \\
\text { pelanggan } \\
\begin{array}{l}\mathrm{H}_{5}: \text { Contact Personnel berpengaruh } \\
\text { positif terhadap kepercayaan } \\
\text { pelanggan }\end{array}\end{array}$ & 1,692 & 1,661 & $\mathrm{H}_{4}$ diterima \\
\hline $\begin{array}{l}\mathrm{H}_{5}: \text { Contact Personnel berpengaruh } \\
\text { positif terhadap kepercayaan } \\
\text { pelanggan }\end{array}$ & 5,833 & 1,661 & $\mathrm{H}_{5}$ diterima \\
\hline $\begin{array}{l}\mathrm{H}_{6}: \text { Citra rumah sakit berpengaruh } \\
\text { positif terhadap kepercayaa } \\
\text { pelanggan }\end{array}$ & 3,528 & 1,661 & $\mathrm{H}_{6}$ diterima \\
\hline
\end{tabular}

Pengaruh langsung, tidak langsung dan pengaruh total

Dari hasil analisis substruktur pada koefisien jalur, diperoleh hasil pengaruh langsung, pengaruh tidak langsung dan pengaruh total masing-masing variable sebagai berikut:

\begin{tabular}{|l|c|c|c|}
\hline \multicolumn{1}{|c|}{ Jalur } & $\begin{array}{c}\text { Pengaruh } \\
\text { langsung }\end{array}$ & $\begin{array}{c}\text { Pengaruh Tidak } \\
\text { Langsung }\end{array}$ & $\begin{array}{c}\text { Pengaruh } \\
\text { Total }\end{array}$ \\
\hline $\begin{array}{l}\text { Pengaruh pysical support } \\
\text { terhadap Citra Rumah } \\
\text { Sakit }\end{array}$ & 0,329 & - & - \\
\hline $\begin{array}{l}\text { Pengaruh contact } \\
\text { personnel terhadap citra } \\
\text { rumah sakit }\end{array}$ & 0,135 & - & - \\
\hline $\begin{array}{l}\text { Pengaruh pysical support } \\
\text { terhadap kepercayaan } \\
\text { pelanggan }\end{array}$ & 0,159 & 0,0809 & 0,525 \\
\hline $\begin{array}{l}\text { Pengaruh contact } \\
\text { personnel terhadap } \\
\text { kepercayaan pelanggan }\end{array}$ & 0,521 & 0,3321 & 0,381 \\
\hline $\begin{array}{l}\text { Pengaruh citra rumah sakit } \\
\text { terhadap kepercayaan } \\
\text { pelanggan }\end{array}$ & 0,246 & - & - \\
\hline
\end{tabular}


Hasil penelitian menunjukkan bahwa pysical support berpengaruh pada contact personel. Temuan ini mengindikasikan bahwa dukungan fisik yang terdapat di rumah sakit seperti lokasi rumah sakit, peralatan yang dimiliki, peralatan pelayanan pengguna, ketersediaan obat dan fasilitas penunjang (parker, ruang tunggu) berdampak bagi terciptanya kemudahan dalam malakukan kontak personal antara anggota organisasi (administrasi, perawat, dokter, apoteker) dengan pihak pengguna layanan rumah sakir (masyarakat). Ketersedaiaan fasilitas dan peralatan yang memadai akan mendorong anggota oragnisasi dapat memberikan pelayanan yang lebih baik pada pengguna RS. Sarana fisik penting dalam mendukung proses pelayanan prima pada rumah sakit.

Sebagai high contact service, personnel pada rumah sakit merupakan sentral dari penyampaian jasa. Sesuai dengan pendapat Lovelock dan Wright (2002) bahwa "in hight-contact services, service personnel are central to service delivery.' Lebih lanjut Lovelock dan Wright (2002) menyatakan bahwa,"in the eyes of their customers, sevice personnel may also be seen as an integral part of the service experience. Temuan ini selaras dengan beberapa temuan sebelumnya yang dilakukan oleh Lita (2003); Setiorini (2010); Rahab (2011) yang melaporkan bahwa ada korelasi positif pysical support dengan contact personel.

\section{Pengaruh Physical Support Pada Citra Rumah Sakit}

Hasil penelitian memperlihatkan adanya pengaruh positif physical support pada citra rumah sakit. Hal ini menunjukan bahwa citra rumah sakit di wilayah Kabupaten Banyumas dipengaruhi oleh physical support yang melekat pada setiap rumah sakit. Sistem penyampaian jasa berupa physical support berperan penting dalam dalam membentuk persepsi positif pengguna terhadap rumah sakit.

Dalam literatur pemasaran, pengaruh keadaan fisik dari suatu objek dikenal dengan istilah "tangibility". Melalui hal-hal yang bisa diamati secara kasat mata oleh konsumen tersebut, citra suatu rumah sakit akan terbentuk dalam benak konsumen. Kondisi fisik bangunan yang dapat diamati konsumen tersebut meliputi kondisi eksterior dan interior gedung, lay out ruangan, tingkat keamanan, tingkat kenyamanan, tingkat kebersihan, lokasi rumah sakit serta kelengkapan fasilitas medis yang dimiliki rumah sakit. Cooper (1994) menemukan bahwa kualitas Dokter, fasilitas perawatan dan teknologi, fasilitas diagnosa, kualitas perawatan keseluruhan, perhatian interpersonal, kesadaran staf terhadap kebutuhan personal pasien, kontrol pasien dari pengalaman rumah sakit, lokasi dan biaya, kemudahan dari lokasi berpengaruh terhadap citra rumah sakit. Dengan menciptakan suasana dan perawatan fasilitas fisik yang berkelanjutan, pihak rumah sakit dapat membentuk citra positif di mata konsumennya. Hal tersebut dapat berdampak pada tingginya minat konsumen untuk berobat di rumah sakit yang bersangkutan.

Keller (1993) seperti yang dikutip oleh Adreassen menyatakan bahwa pada tingkat perusahaan, citra dapat diartikan sebagai persepsi suatu organisasi yang tercermin berupa asosiasi dalam ingatan konsumen. Citra perusahaan ditentukan oleh bagaimana interpretasi tentang identitas perusahaan, yang membentuk keseluruhan kesan atau persepsi dalam pikiran konsumen (Thomas dan Hill, 1999). Temuan penelitian ini selaras dengan beberapa hasil penelitian sebelumnya pada kontek RS di Indonesia. Lita (2003) yang menyatakan bahwa physical support sebagai komponen dari sistem penyampain jasa rumah sakit berpengaruh pada citra rumah sakit di wilayah sumatra barat. Hal yang sama juga dilaporkan oleh Setiorini (2010) yang menemukan bahwa physical support mempunyai pengaruh pada citra rumah sakit Umum di kabupaten Situbondo. Rahab (2011) juga menemukan bahwa dukungan fisik memiliki kontribusi dalam meningkatkan citra rumah sakit. 
Pengaruh Contact Personnel Pada Citra Rumah Sakit

Hasil penelitian menunjukkan bahwa contact personnel tidak berpengaruh pada citra rumah sakit. Hal ini menunjukkan bahwa contact personel berupa penampilan tenaga medis, paramedis dan non medis saat memberikan pelayanan, Kemampuan tenaga medis, paramedis dan non medis saat memberikan pelayanan, Cara tenaga medis, paramedis dan non medis saat memberikan pelayanan, Keramahan tenaga medis, paramedis dan non medis saat memberikan pelayanan, Daya tanggap tenaga medis, paramedis dan non medis saat memberikan pelayanan, kecepatan tenaga medis, paramedis dan non medis saat memberikan pelayanan, kemudahan menemui tenaga medis dan paramedis, Ketepatan waktu pelayanan, kemudahan prosedur pelayanan yang diberikan petugas, Kejelasan informasi yang diberikan petugas tidak berdampak langsung pada persepsi pengguna mengenai citra rumah sakit. Hal ini dapat dijelaskan karena sebagian besar responden dalam penelitian (72\%) adalah pengguna rumah sakit dengan pendapatan dibawah Rp 1 juta atau dengan kata lain pengguna dengan kemampuan ekonomi menengah ke bawah.

Pengguna layanan rumah sakit dengan tingkat ekonomi menengah ke bawah cenderung mementingkan aspek pertimbangan biaya daripada layanan yang diberikan kepadanya. Mereka secara ekonomi lemah posisi tawarnya (Indyatuti dan Rahab, 2008). Ketidakmampuan untuk berobat pada rumah sakit swasta karena masalah biaya yang tinggi, mendorong persepsi meraka bahwa apa yang mereka korbankan (biaya) berobat sudah sesuai dengan apa yang mereka terima (layanan). Kondisi ini juga diperkuat oleh adanya program pemerintah berkaitan dengan subsidi biaya kesehatan seperti jamkesmas dimana pasien mendapatkan bantuan biaya berobat dari program tersebut. Fakta ini memperkuat temuan bahwa dengan biaya yang mereka korbankan melebihi apa yang mereka dapatkan, meskipun disadari bahwa secara rumah sakit milik pemerintah secara contact personnel kurang baik dibandingkan dengan contact personnel yang diberikan rumah sakit swasta. Temuan ini selaras dengan hasil temuan Rahab (2011); Puspita (2009) yang menemukan bahwa kontak personal pada kontek rumah sakit pemerintah tidk berpengaruh secara signifikan pada citra rumah sakit. Namun demikian, hasil penelitian ini bertentangan dengan pendapat Gongroos (2000) yang menyatakan bahwa kehandalan kualitas layanan yang diberikan perusahaan kepada pelanggan berdampak bagi citra perusahaan.

\section{Physical Support Berpengaruh Positif Terhadap Kepercayaan Pelanggan}

Hasil penelitian menunjukkan bahwa physical support berpengaruh positif terhadap kepercayaan pelanggan pada rumah sakit di wilayah Kabupaten Banyumas. Temuan ini mengindikasikan bahwa dukungan fisik berupa: fasilitas gedung yang tersedi, ketersediaan peralatan, ketersediaan sarana parkir, kenyamanan rumah sakit, keamanan rumah sakit, ketersediaan fasilitas pendukung, kondisi ruang perawatan, kebersihan rumah sakit, eksterior gedung, interior gedung, kelengkapan obat di apotik, kestrategisan lokasi rumah sakit, penerangan rumah sakit, sirkulasi udara, tata letak ruangan, menu makanan yang disediakan untuk pasien berpengaruh pada kepercayaan pengguna pada rumah sakit. Ketersediaan sarana pendukung yang dimiliki oleh rumah sakit berperan penting dalam mendorong minat pengguna untuk menggunakan kembali rumah sakit tersebut dimasa yang akan datang.

Temuan ini selaras dengan temuan Shamdasani dan Balakrishnan (2000) dalam penelitiannya menemukan bahwa contact personnel, physical environment, customer environment berpengaruh terhadap kepuasan, trust (kepercayaan), dan loyalitas. Taylor dan Baker (1997) juga menemukan bahwa kepuasan pasien terhadap layanan yang diberikan oleh karaywan rumah sakit mempengaruhi intensi untuk menggunakan jasa rumah sakit pada masa yang akan datang. Kepuasan pelanggan mempengaruhi kepercayaan dan kepercayaan mempengaruhi komitmen pelanggan (Bloemer et.al, 
2002). Komitmen pelanggan mempunyai pengaruh yang kuat terhadap intensi pembelian, intensitas harga dan word of mouth (WOM). Menurut hasil penelitian Gaunaris dan Venetis (2002:636) bahwa pengembangan kepercayaan pada diri konsumen berpengaruh langsung terhadap kinerja pelayanan dan keberhasilan untuk menggaet konsumen. Menurut Ravald dan Gronroos (1996) bahwa nilai yang dirasakan konsumen dapat membangun hubungan dengan konsumen, kredibilitas perusahaan, kepercayaan dan loyalitas konsumen.

\section{Pengaruh Contact Personnel Pada Kepercayaan Pelanggan}

Hasil penelitian menunjukkan bahwa contact personnel berpengaruh pada kepercayaan pelanggan. Temuan tersebut mengindikasikan bahwa tingkat kepercayaan pelanggan terhadap pelayanan yang diberikan rumah sakit dipengaruhi oleh hasil evaluasi yang dilakukan pasien atas pelayanan yang diberikan oleh pihak rumah sakit terhadap mereka. Dimensi yang menjadi bahan evaluasi pelanggan tersebut antara lain adalah penampilan, kemampuan meyakinkan pasien, keramahan, ketanggapan, kecepatan pelayanan, kemudahan memperoleh pelayanan, tingkat ketepatan waktu pelyanan serta kejelasan informasi yang diberikan oleh pihak rumah sakit. Hasil interaksi dengan contact personnel rumah sakit akan menghasilkan suatu evaluasi dalam diri pasien sebagai konsumen rumah sakit sehingga kemudian juga akan berdampak pada tingkat kepercayaan pelanggan terhadap rumah sakit. Semakin tinggi tingkat kepercayaan yang diberikan pelanggan terhadap pelayanan rumah sakit, maka akan semakin tinggi pula tingkat loyalitas yang dimiliki pelanggan terhadap rumah sakit. Lita (2003) menemukan bahwa contact personal berpengaruh pada kepercayaan pengguna rumah sakit di wilayah Sumatra barat. Hal serupa dilaporkan oleh Setiorini (2010) dalam penelitiannya menemukan bahwa terdapat hubungan positif antara contact personal dengan kepercayaan pengguna rumah sakit di Situbondo, Jawa Timur.

Kepercayaan pelanggan erat kaitannya dengan loyalitas. Loyalitas yang tinggi dari pelanggan selanjutnya akan memberikan riffle effect yang lebih besar bagi rumah sakit dengan adanya Word of Mouth Marketing yang dilakukan oleh pelanggan rumah sakit terhadap calon konsumen rumah sakit yang baru. Word of Mouth Marketing yang dilakukan oleh pelanggan merupakan cara yang efektif dan sekaligus ekonomis bagi pihak rumah sakit untuk dapat meningkatkan jumlah konsumen di masa datang. Komitmen pelanggan mempunyai pengaruh yang kuat terhadap intensi pembelian, intensitas harga dan word of mouth (WOM). Menurut hasil penelitian Gaunaris dan Venetis (2002:636) menemukan pengembangan kepercayaan pada diri konsumen berpengaruh langsung terhadap kinerja pelayanan dan keberhasilan untuk menggaet konsumen. Menurut Ravald dan Gronroos (1996) bahwa nilai yang dirasakan konsumen dapat membangun hubungan dengan konsumen, kredibilitas perusahaan, kepercayaan dan loyalitas konsumen.

\section{Pengaruh Citra Rumah Sakit Pada Kepercayaan Pelanggan}

Hasil penelitian menunjukkan bahwa citra rumah sakit berpengaruh pada kepercayaan pengguna pada RS. Pemasaran yang efektif bagi pihak rumah sakit di wilayah Kabupaten Banyumas tergantung pada pengembangan dan pengelolaan kepercayaan pengguna sehingga sehingga pengguna secara khusus membeli suatu jasa sebelum mengalaminya (Shamdasani dan Balakrishnan, 2000). Pengelolaan kepercayaan ditentukan dengan cara yang mana sumber daya-sumber daya pemberi jasa, personal, teknologi dan sistem, yang digunakan supaya kepercayaan pelanggan pada sumber daya yang terlibat dan perusahaan itu sendiri, dipertahankan dan diperkuat (Granroos, 1990 dikutip oleh Shamdasani dan Balakrishnan, 2000). Lita dalam penelitiannnya menujukkan bahwa citra rumah sakit berpengaruh langsung pada kepercayaan pengguna RS. Hal yang sama juga dilaporkan oleh setiorini (2010) yang menekukan bahwa variabel citra rumah sakit berpengaruh secara signifikan pada kepercayaan pengguna rumah sakit. 
Rousseau (1998) menyatakan kepercayaan (trust) adalah keadaan psikologis berisi keinginan untuk menerima kekurangan/kelemahan, berdasarkan perilaku yang positif terhadap intensi atau perilaku atau lainnya dalam keadaan berisiko dan saling tergantung, sedangkan Robbin (2003) menyatakan kepercayaan (trust) merupakan harapan yang positif bahwa yang lain tidak akan bertindak secara oportunistic.

Donney and Cannon (1997) mendefinisikan "Trust as perceived credibility and benevolence of a target of trust." Dari definisi ini trust dapat dilihat dari dua dimensi. Dimensi pertama adalah credibility of an exchange partner, and ecpectancy that the partner word or written statement can be relied on. Dimensi kedua benevolence is the extent to wish one partner is genuinely interested in the other partner's welfare and motivated to seek joint again. Kredibilitas suatu rumah sakit dapat dipersepsikan sebagai citra yang dipersepsikan pengguna pada rumah sakit tersebut. Oleh karenanya para pengguna yang mempersepsikan bahwa rumah sakit di wilayah Kabupaten Banyumas memiliki citra positif/baik maka akan berdampak pada kepercayaan pengguna pada rumah sakit tersebut.

Dalam membentuk kepercayaan bagi pengguna membutuhkan waktu dan proses yang lama dan membutuhkan upaya yang serius bagi pihak rumah sakit. Apabila kepercayaan sudah terjalin di antara pelanggan dan perusahaan akan terbetuk loyalitas pengguna. Kepercayaan pengguna rumah sakit diyakini berperan dalam pembentukan persepsi pengguna terhadap rumah sakit.

Kepercayaan (trust) adalah dasar dari stategic partnership bagi institusi rumah sakit, karena hubungan perusahaan dan pelanggan yang dilandasi kepercayaan (trust) sangat dihargai, sehingga pihak-pihak yang berkepentingan akan sangat ingin berkomitmen ke dalam hubungan yang memberikan manfaat timbale balik. Oleh karena upaya membangun kepercayaan pengguna rumah sakit diperlukan adanya adanya komitmen pengelola rumah sakit untuk memberikan layanan terbaik bagi pasien atau pengguna rumah sakit. Peningkatan layanan bagi pengguna rumah sakit merupakan strategi yang efektif guna membangun kepercayaan pengguna pada rumah sakit. Garbarino dan Johnson (1999) juga lebih menekankan pada individual trust dengan mengacu kepada keyakinan konsumen atas kualitas dan keterandalan jasa yang diberikan.

\section{SIMPULAN DAN IMPLIKASI}

Berdasarkan hasil penelitian dan pembahasan maka dari hasil penelitian yang telah dilakukan akan dapat diambil kesimpulan sebagai berikut:

a. Physical support yaitu kelayakan fasilitas gedung, ketersediaan peralatan, kenyamanan, keamanan, kondisi ruangan, kebersihan, eksterior, interior, kelengkapan obat di apotik, kestrategisan lokasi, sirkulasi udara, makanan yang disediakan dan tata letak ruangan rumah sakit dinilai lebih tinggi daripada ketersediaan tempat parkir dan fasilitas pendukung. Contact personnel yaitu penampilan, kemampuan, daya tanggap, kecepatan, ketepatan dan prosedur pelayanan yang diberikan petugas pada rumah sakit dinilai lebih tinggi daripada keramahan,kemudahan menemui dan memperoleh informasi dari petugas. Citra rumah sakit yaitu pendapat keseluruhan mengenai rumah sakit dan kesukaan terhadap rumah sakit dinilai cukup tinggi daripada kontribusi rumah sakit kepada masyarakat.

b. Terdapat hubungan antara physical support dengan contact personnel pada rumah sakit umum di Kabupaten Banyumas. Temuan ini menunjukkan bahwa physical support memerlukan dukungan contact personnel dalam melayani pelanggan, sedangkan di sisi lain contact personnel akan mampu bekerja dengan baik melayani pelanggan, apabila didukung oleh physical support yang memadai.

c. Variabel sistem penyampaian jasa yang berpengaruh terhadap citra rumah sakit umum di wilayah Kabupaten Banyumas hanya physical support. Temuan ini menunjukkan bahwa pengguna rumah sakit milik pemerintah di wilayah Kabupaten Banyumas 
memandang citra rumah sakit umum. Lebih didasarkan pada dukungan fisik RS dari pada contact personel yang diberikan kepadanya.

d. Secara parsial, (1) physical support berpengaruh pada contact personel. (2) physical support berpengaruh pada citra rumah sakit. (3) physical support dan contact berpengaruh pada kepercayaan pelanggan, (4) citra rumah sakit berpengaruh terhadap kepercayaan pelanggan. Temuan ini menunjukkan bahwa sistem penyampain jasa berupa physical support dan contact personel efektif meningkatkan kepercayaan pelanggan, apabila didukung oleh citra rumah sakit yang baik.

e. Temuan penelitian ini didukung teori yang ada dan dapat memberikan manfaat dalam hal pengembangan ilmu manajemen pemasaran, melalui pendekatan dan metodemetode yang digunakan, terutama pengaruh sistem penyampaian jasa yang meliputi physical support dan contact personnel terhadap citra rumah sakit dan kepercayaan pelanggan pada rumah sakit milik pemerintah di Kabupaten Banyumas.

Berdasarkan hasil dan kesimpulan penelitian maka dapat diajukan saran sebagai berikut:

1. Pihak rumah sakit untuk lebih memperhatikan sistem penyampaian yang meliputi physical support dan contact personnel, terutama fasilitas parkir, ketersediaan fasilitas pendukung, keramahan paramedis, kemudahan menemui tenaga medis dan kemudahan memperoleh informasi dari petugas, serta meningkatkan citra rumah sakit dengan cara meningkatkan kontribusi rumah sakit kepada masyarakat yaitu dengan memberikan perhatian terhadap masyarakat seperti melakukan kegiatan sosial (pengobatan/perawatan gratis bagi masyarakat kurang mampu, sunatan masal dan penyuluhan) dan diharapkan juga membantu meningkatkan pendidikan masyarakat di lingkungannya, seperti memberikan beasiswa untuk lembaga pendidikan, kegiatan seminar, sebagai tempat pelatihan dan pendidikan dan sebagainya.

2. Pihak rumah sakit untuk lebih memperhatikan adanya hubungan antara physical support dan contact personnel serta lebih berorientasi pelanggan, dengan menekankan kepada semua petugas bahwa rumah sakit tak bisa hidup tanpa adanya pelanggan dengan cara, (1) tenaga medis (dokter) yang mendahulukan kepentingan pasien dan pihak rumah sakit terutama rumah sakit swasta meninjau kembali kerjasama dengan dokter spesialis tidak tetapnya, sehingga waktu pemeriksaan tepat waktu, (2) petugas medis, non medis dan paramedis harus melayani pasien dengan ramah, cepat dan tanggap, seperti mengucapkan salam dan senyum jika bertemu pelanggan, tanggap dan cepat jika pelanggan membutuhkannya, (3) menyediakan sistem pendidikan dan pelatihan untuk petugas medis, paramedis dan non medis untuk meningkatkan kemampuan dalam melayani pelanggan dan penggunaan peralatan medis dan non medis di rumah sakit, sehingga petugas bisa dengan cepat melayani pelanggan, dan (4) pihak rumah sakit diharapkan meningkatkan, melengkapi, memelihara dan merenovasi fasilitas fisik yang dimiliki rumah sakit seperti fasilitas pendukung, batas dan area parkir, kebersihan dan taman.

3. Pihak rumah sakit diharapkan meningkatkan sistem penyampaian jasa yang meliputi physical support dan contact personnel serta citra rumah sakit secara terus menerus karena mempengaruhi kepercayaan pelanggan. Pihak rumah sakit diharapkan mempunyai sistem complain dengan menerima masukan dari pelanggan dengan cara: (1) menyediakan kotak saran atau unit yang menangani keluhan pelanggan, sehingga bisa mengetahui dengan jelas apa permasalahan yang dihadapi pelanggan dan berusaha mencari solusinya, (2) melakukan survey kebutuhan dan preferensi untuk mengetahui kebutuhan dan preferensi pelanggan, dan dijadikan bahan masukan untuk merancang program pemasaran terutama sistem penyampaian jasa.

4. Penelitian yang dilakukan pada rumah sakit umum di Kabupaten Banyumas masih terbatas pada variabel sistem penyampaian jasa, citra rumah sakit dan kepercayaaan pelanggan. Untuk penelitian selanjutnya bisa dikembangkan dengan menambahkan variabel lain seperti sistem operasi jasa, pengalaman pelanggan dan melanjutkan dengan melihat pengaruh terhadap komitmen pelanggan, intensi untuk kembali dan intensi untuk merekomendasikan. 
Keterbatasan Penelitian

Berdasarkan perhitungan $R$ square penelitian dari substruktur 1 diperoleh hasil bahwa physical support dan contact personnel secara gabungan hanya mampu mempengaruhi citra rumah sakit di wilayah Kabupaten Banyumas sebesar 18,3\% saja, sedangkan citra rumah sakit dipengaruhi oleh variabel lain di luar model regresi tersebut sebesar $81,7 \%$. Dengan demikian, penelitian ini belum mampu mengungkap sepenuhnya variabel-variabel lain yang mampu mempengaruhi citra rumah sakit di mata pelnggannya. Penelitian dimasa yang akan dimungkinkan untuk memasukkan variabel lain seperti: kepuasan pelanggan sebagai variabel mediasi hubungan antara sistem penyampain jasa dengan citra rumah sakit. Variabel pendapatan dimungkinkan berpengaruh pada persepsi pengguna RS menegnai sistem penyampaian jasa rumah sakit Perlu adanya pengujian terhadap perbedaan pendapatan pengguna rumah sakit sebabai variabel moderasi hubungan antara sistem penyampaian jasa dengan citra rumah sakit maupun pada kepercayaan pelanggan rumah sakit.

\section{DAFTAR PUSTAKA}

Achmad Hardiman. 2003. Rumah Sakit Indonesia Belum Siap Bersaing. Melalui http://www.kompas.com/kompas-cetakr/0412/22/humanioral455383 $\mathrm{html}$ 4k. [4/21/04].

Andreassen, Tor Wallin and Bodil Lindestad. 1998. The Impact of Corporate Image on Quality, customer Satisfaction and Loyalty for Customers with Varying degrees of Service Expertise. International Journal of Service Industry Management vol.9 No.1: 723.

Assael, Henry. 1992. Consumer Behavior and Marketing Action. Boston: PWS- KENT Publishing Company: 194-221.

Balthasar Elu. 2004. Strategi Manajemen Pemasaran Jasa Kesehatan. Jakarta: Manajemen Usahawan Indonesia No.06/TH.XXXIII Juni 2004: 35-40.

Belanger, Charles, Joan Mount and Mathew Wilson. 2002. Institutional Image and Retention. Tertiary Education and Managemenet 8: 217-230.

Best, Rogers. 2000. Market Based Management. Strategies for Growing, Customer Value and Profitability. Upper Saddle River New Jersey: Prentice Hall: 205-230.

Bologlu, Seyhmus. 2002. Dimensions of Customer Loyalty-Separating Friends from Well Wishers Cornell Hotel and Restaurant. Administration Quarterly, Cornel University: 49-50.

Boy S.Sabarguna. 2004. Pemasaran Rumah Sakit. Yogyakarta: Konsorsium RSI: 1-21.

Buchari Alma. 2005. Manajemen Pemasaran dan Pemasaran Jasa. Bandung: Alfabeta: 370-385.

Caruana, Albert. 1998. The Effect of Internal Marketing on Organizational Commitment among Retail Bank Managers. International Journal of Bank Marketing 16/3: 108-116.

Cooper, Philip D. 1994. Health Care Marketing: A Foundation For Managed Quality. Gaithersburg, Maryland: Aspen Publisher, Inc.: 1-331.

Darmanto Djojodibroto. 1997. Kiat Mengelola Rumah Sakit. Jakarta. Penerbit Hipokrates:131-137.

Goncalves Karen P. 1998. Service Marketing A Strategi Approach. Upper Saddle River New Jersey: Prentice Hall: 1-80.

Gudmundson dan Cristine. 2002. Internal Marketing: A Way of Improving Service Quality. Sweden: Ostersund: 6-12.

Hanif Mauludin. M. (tanpa tahun). Analisis Kualitas Pelayanan, Pengaruhnya terhadap Image (Studi pada Penderita Rawat Inap Rumah Sakit). Melalui http://www.directessays.com/veewpaper/html.18k. [4/21/04]. 
Hawkins, Del I, Roger J Best and Kenneth A Coney. 2004. Consumer Behavior, Building Marketing Strategy. New York: Mc Graw Hill Companies, Inc.: 625-651.

Heskett, James L, Earl Sasser Jr and Leornard A Schlesinger.1997. The Service Profit Chain: How Leading Companies Link Profit and Growth to Loyalty, Satisfaction, and Value. New York: The Free Press, Simon \& Schuster: 9- 19.

Hutton, James D and Lynne Richardson. 1995. Healthscapes: The Role of Facility and Physical Environment on Consumer Attitudes, Satisfaction, Quality assessments, and Behaviors. Health Care Management Review 20: 48-60.

Kotler, Philip. 2003. Marketing Management. Engelwood Cliffs: Prentice Hall International Inc. A Division of Simoon and Scuster: 64-451.

Kurt, David L and Kenneth Clow.1998. Service Marketing. Singapore. John Wiley \& Sons, Inc.: 24-30.

Leblanc, Gaston and Nha Nguyen. 1996. Cues Used by Cutomers Evaluating Corporote Image in Service Firms: An Empirical study in Financial Institutions. Coorporate Communication: An International Journal 2: 30- 38.

Lim, Cheng Puay and Nelson K.H.Tang.2000. A Study of Patients Expectation and Satisfaction in Singapore Hospital International. Journal of Health Care Quality Assurance 13 No.7: 290-299.

Lovelock, Christoper. 2001. Service Marketing, People, Technology, Strategy. USA: Prentice Hall Internasional. Inc.: 54-80.

Nguyen, Nha and Gaston Leblanc. 2002. Contact Personnel, Physical Environment and Perceived Corporate Image of Intangible Services by New Clients. International Journal of Service Industry Management 13: 242-262.

Puspita, Ita.2009. Hubungan antara persepsi pasien tentang kualitas dengan citra Rumah sakit Umum Daerah Kabupaten Aceh Tamiang, Tesis. Universitas Sumatera Utara, Tidak dipublikasikan.

Rahab.2011. Peran Dukungan Fisik dan Kontak Personal Pada Peningkatan Citra Rumah Sakit Milik Pemerintah. Proceding Seminar Akademik Manajemen dan Bisnis, Universitas Muhamadiyah Surakarta, 28 Mei 2011.

Riordan, Christine, Robert.D.Gatewood and Jodi Barnes Bill. 1997. Corporote Image: Employee Reaction and Implications for Managing Corporate Social Performance. Journal of Business Ethics 16: 401-412.

Sarwono, Jonathan. 2007. Analisis Jalur Untuk Riset Bisnis Dengan SPSS. Penerbit Andi, Yogyakarta

Setiorini, Indah Letari. 2010. Pengaruh Physical Support Dan Contact Personel Terhadap Citra (Image) Dan Kepercayaan Pasien Pada Rumah Sakit Umum Situbondo. Skripsi. Universitas Jember, Tidak dipublikasikan.

Shamdasani, Prem N and Audrey Balakrishnan. 2000. Determinants of Relationship Quality and Loyalty in Personalized Services. Asia Pacific Journal of Management 17: 399-22.

Snook, I Donald. 1992. Hospitals, What They Are and How They Work. Gaithersburg, Maryland: An Aspen Publishers, Inc.: 65-89.

Taylor, Thomas L. and Steven A. Baker. 1997. Patient Satisfaction and Service Quality in the Formation of Customers' Future Purchase Intentions in Competitive Health Service Setting. Health Marketing Quarterly 15: 1-15.

Taylor, Stephen A. 2001. Assessing the Use of Regression Analysis in Examining Service Recovery in the Insurance Industry Relating Service Quality, Customer Satisfaction and Customer Trust. Journal of Insurance Issues 24:30- 57. 
Tjandra Yoga Aditama. 2003. Manajemen Administrasi Rumah Sakit. Jakarta: Universitas Indonesia: 169-241.

Zeithaml, Valarie A and Mary Jo Bitner. 2000. Service Marketing. Singapore: Mc Graw-Hill Companies Inc.: 3-287. 